IRA-International Journal of Applied Sciences ISSN 2455-4499; Vol.04, Issue 03 (2016)

Institute of Research Advances

Pg. no. 471-481

http://research-advances.org/index.php/IRAJAS

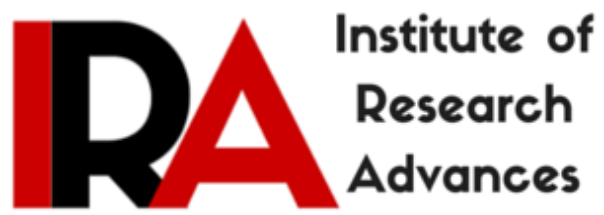

\title{
Screening of antinutrients in leaves, fruit pulp and seeds of Gishta (Annona spp.) of Ethiopia, North East Africa
}

\author{
Harikrishna Ramaprasad Saripalli ${ }^{1}$, Prasanna Kumar Dixit ${ }^{2}$ \\ ${ }^{1}$ Research Scholar (D.Sc in Biotechnology), Berhampur University, \\ Bhanja Bihar, Berhampur-760007 (Odisha), India. \\ ${ }^{1}$ Associate Professor, Department of Biotechnology, \\ College of Natural and Computational Sciences, Aksum University, \\ Axum, Ethiopia P.O. Box: 1010, North East Africa. \\ ${ }^{2}$ Associate Professor, Department of Zoology, Berhampur University, \\ Bhanja Bihar, Berhampur-760007 (Odisha), India.
}

Type of Review: Peer Reviewed.

DOI: http://dx.doi.org/10.21013/jas.v4.n3.p11

\section{How to cite this paper:}

Saripalli, H., \& Dixit, P. (2016). Screening of antinutrients in leaves, fruit pulp and seeds of Gishta (Annona spp.) of Ethiopia, North East Africa. IRA-International Journal of Applied Sciences (ISSN 2455-4499), 4(3), 471-481.

doi:http://dx.doi.org/10.21013/jas.v4.n3.p11

(C) Institute of Research Advances

\section{(cc) BY-NC}

This work is licensed under a Creative Commons Attribution-Non Commercial 4.0 International License subject to proper citation to the publication source of the work.

Disclaimer: The scholarly papers as reviewed and published by the Institute of Research Advances (IRA) are the views and opinions of their respective authors and are not the views or opinions of the IRA. The IRA disclaims of any harm or loss caused due to the published content to any party. 


\begin{abstract}
Graviola or Gishta (Annona spp. of Ethiopia) are generally useful for human consumption were analysed for the presence of potentially harmful chemicals (antinutrients) and for their toxicity. The purpose of the study was to determine whether the Graviola or Gishta (Annona spp. of Ethiopia) leaves, fruit pulp and seed extracts were safe for human consumption. Chemical analysis showed that none of tested parts contained cyanogenic glycosides, however all the three tested plant materials contained oxalic acid in high concentrations and also contained negligible amounts of phytic acid, saponins and alkaloids. Tested plant samples also found to inhibit trypsin activity. These chemical analyses were carried out in duplicate.
\end{abstract}

KEY WORDS: Gishta, Graviola, Annona spp., and Antinutrients.

\title{
INTRODUCTION
}

Plants consumed by human beings should be free of toxicity or other adverse effects on their consumer. Common indicators of unsafe plants include their toxic, cytotoxic and mutagenic potential. These harmful properties of plants are produced by the antinutrient chemicals that are produced in certain plants as defense mechanisms. Antinutrient are chemical compounds produced in plants as a defense mechanism that inhibits the action of digestive enzymes in insects that attack plants (Lea and Leegood, 1999). These compounds may decrease the nutritional value of a plant food, usually by making an essential nutrient unavailable or indigestible when consumed by humans or animals. A common strategy of plants is to produce foul-tasting compounds such as many bitter nitrogen containing alkaloids, glucosinolates and cyanogenic glucosides. Plants are capable of bioconverting promutagens into toxic metabolites (Grant, 1998). Experimental studies found many 'edible' and medicinal plants to be mutagenic in vitro (Higashimoto et al., 1993; Kassie et al., 1998). According to statistics of the Poison Unit of the Johannesburg General Hospital, about $6.5 \%$ of all poisoning cases are plant related (Van Wyk et al., 2002). Antinutritional components such as oxalic acid, nitrate and erucic acid that are present in many plants (Guil et al., 1996; Siddhuraju et al., 2002)) increase the toxicity of edible plants. These substances may express cytotoxic and genotoxic activities upon consumption and show correlation with tumour development (Yen et al., 2001). This raises concern about the potential hazards resulting from the longterm use of such plants. Some of the common groups of antinutrients are phytic acid, saponins, alkaloids, cyanogenic gycosides, trypsin inhibitors and oxalic acid.

Graviola is a fruit bearing tree, flowering, broadleaf and evergreen which is native to South America, Central America and the Caribbean. The tree is also found in Colombia, Brazil and even the sub-Saharan countries of Africa. Graviola is adaptive to areas with high humidity and also relatively warm temperatures. The laboratory and field research suggests soursop extract substance has potential to various future applications such as, they have shown cytotoxic and anti-leishmanial also anti-diabetic, anti-cancer, anti-inflammatory and anti-nociceptive activities. Soursop (scientific name - Annona muricata), also called Graviola (Portuguese), is a fruit that generally grows in the rain forests of Africa, South America, and Southeast Asia. It has other names like thorny custard apple, cherimoya and brazilian pawpaw. In various languages, this fruit is referred as: guanabana (Spanish), corossol (French), gishta Scientific name - Annona senegelensis (Ethiopia), aluguntugui (Ghana), sorsaka (Papiamento), adunu (Acholi), guyabano, guanavana, durian benggala, nangka blanda, sirsak, toge-banreisi, nangka londa and zuurzak. In India, it is less known as shul-ram-fal and hanuman fal, and as mullaatha in Malayalam (Harikrishna Ramaprasad Saripalli and Prasanna Kumar Dixit, 2016; Blackherbals, 2012).

The bark, leaves, root and fruits of this tree are used for traditional remedies in many countries. Graviola extracts are used for treating infections of viruses or parasites, rheumatism, arthritis, diarrhea, dysentery, depression and sickness. In foods, graviola is used in cooking and beverages. More evidence is needed to rate the effectiveness of graviola for these uses (Harikrishna Ramaprasad Saripalli and Prasanna Kumar Dixit, 2016; Blackherbals, 2012). 
The use of Soursop can have certain adverse effects in some people, especially movement disorders and nerve damage results movement disorders similar to Parkinson's disease, which is due to the very high concentration of annonacin. Consumption of Graviola is unsafe. It can kill nerve cells in the brain and other parts of the body. The Memorial Sloan-Kettering Cancer Center cautions, "alkaloids extracted from graviola may cause neuronal dysfunction and degeneration. Graviola also has few other side effects like lowering the blood pressure, so it should not be taken by people with low blood pressure or heart complications. The antimicrobial properties of Soursop can also kill beneficial bacteria on the skin, in the vagina and gut, which can lead to infections in long term use (Cancer Center, 2013).

In 2010 the French food safety agency (Agence française de sécurité sanitaire des aliments) concluded that, it is not possible to confirm the presence of antinutrients (toxic metabolites) in the genus Annona spp. so, calling for further study on potential risks (Avis de, 2010).

This practically indicates that parts of the same plant contain both toxic and well being substances. There is, however, no experimental evidence that it consists of toxic metabolites(Cancer Research UK, 2013). In view of the above controversial claims, it becomes imperative to carry out conclusive biochemical investigations on Graviola or Gishta (Annona spp. of Ethiopia) leaves, fruit pulp and seed extracts to find out the presence of antinutrients/toxic substances.

\section{OBJECTIVE OF THE STUDY}

To investigate the presence of antinutrients in leaves, fruit pulp and seed extracts of Graviola or Gishta (Annona spp. of Ethiopia) using chemical analysis methods.

\section{MATERIALS AND METHODS}

\section{Collection of Plant Material and Sample preparation}

Graviola or Gishta (Annona spp. of Ethiopia) leaves, fruit pulp and seeds were collected from Oromeo region, Ethiopia, in January 2014. The plant was identified, authenticated and supplied by Prof Behailu Etana Disasa of Natural Resource Management, College of Agriculture and Veterinary Medicine, Jimma University, Jimma, Ethiopia. The plant materials were shade-dried and coarsely powdered. The coarse powder was used for antinutrients studies.

\section{Tested material}

The dried materials of leaves, fruit pulp and seeds of Graviola or Gishta (Annona spp. of Ethiopia) were tested for antinutrients screening.

\section{Chemicals used}

Fe (III)- sulphosalicylate, trichloroacetic acid, $\mathrm{FeCl} 3, \mathrm{NaOH}, \mathrm{dH} 2 \mathrm{O}, \mathrm{HNO} 3$, potassium thiocyanate (KSCN), $80 \%$ methanol, blood agar, $10 \%$ acetic acid in ethanol, chloroform, tyrosine, casein bovine substrate, Folin Ciocalteau (FC) reagent, Tyrosine (Sigma, USA), 80:20 HPLC grade methanol: 0.4\% acetic acid $v / v, 0.025 \mathrm{M} \mathrm{HCl}$ was used during experimental protocol.

\section{Instruments used}

Shaking incubator, centrifuged, Whatman No. 2 filter paper, Spectrophotometer, Whatman no.1, rotary evaporator, sodium picrate paper, isocratic reverse phase high performance liquid chromatography (HPLC), Phenomenex C18 solid-phase extraction cartridge was used during chemical analysis. 
Table. 1. Antinutrients (toxic substances) and their analytical approach with references.

\begin{tabular}{|c|c|c|c|}
\hline S.No & Antinutrient & Method and Technique & Reference \\
\hline 1. & Phytic acid & Spectrophotometric Method & $\begin{array}{c}\text { Omotoso (2006); Wheeler and } \\
\text { Ferrel (1971) }\end{array}$ \\
\hline 2. & Saponins & $\begin{array}{c}\text { Disc Diffusion Method (Haemolytic } \\
\text { Property) }\end{array}$ & Makkar (2004) \\
\hline 3. & Alkaloids & Precipitation method & $\begin{array}{c}\text { Harikrishna Ramaprasad } \\
\text { Saripalli (2012); Edeoga et al. } \text {. } \\
\text { (2005; 2000); Harborne (1984); }\end{array}$ \\
\hline 4. & $\begin{array}{l}\text { Cyanogenic } \\
\text { glycosides }\end{array}$ & Picrate-Impregnated Paper Technique & Tan and Yeoh (1997). \\
\hline 5. & $\begin{array}{l}\text { Trypsin } \\
\text { inhibitors }\end{array}$ & Activity Determined By Fc Reagent & Jayaraman (1981). \\
\hline 6. & Oxalic acid. & Isocratic Reverse Phase HPLC Analysis & Miller and Woodrow (2004). \\
\hline
\end{tabular}

\section{Antinutrients studies (Toxic metabolites)}

The solvent extracts of leaves, fruit pulp and seeds of Graviola or Gishta (Annona spp. of Ethiopia) were assayed for the Antinutrients such as phytic acid, saponins, alkaloids, cyanogenic glycosides, trypsin inhibitors and oxalic acid. In all antinutrient assays, $5 \mathrm{~g}$ of oven dried, crushed material was used, except for oxalic acid analysis where $0.5 \mathrm{~g}$ of crushed material was used. Special methods used for each antinutrient are clearly given in the table.1.

\section{RESULTS}

\section{Phytic Acid}

The concentration of phytic acid was determined spectrophotometrically in three tested plant materials of Gishta as shown in table 2. The concentrations of phytic acid were obtained from $5 \mathrm{~g}$ dried leafy material. All the leaf samples contained phytic acid (detection limit $0.025 \mathrm{mg} / \mathrm{ml}$ ) in this study. This may have been due to the fact that there was a limitation in terms of the detection concentration since concentrations less than mg was not tested. Seed extracts was found to contain the highest concentration of phytates with a concentration of $0.39 \mathrm{mg} / \mathrm{ml}$. leaf extracts contained phytates even though it was detected at a low concentration of $0.06 \mathrm{mg} / \mathrm{ml}$. whereas fruit pulp extracts had a concentration of $0.17 \mathrm{mg} / \mathrm{ml}$.

\section{Saponins}

Saponins were detected by the presence of haemolytic zones on blood agar plates using the disc diffusion method (Figure 1). The concentrations of saponins were obtained from $5 \mathrm{~g}$ dried plant material. A standard curve was drawn and used to determine concentration of saponins in the three types plant material extracts of Gishta. These zones were used to draw up a standard curve and the unknown concentrations of saponins in the samples were determined. Saponins were not found in all the testes samples of Gishta. ranging from 0.59 to $1.7 \mathrm{mg} / \mathrm{ml}$. Seeds contained the highest concentration $(1.7 \mathrm{mg} / \mathrm{ml})$ which is very close to the saponin standard $(2 \mathrm{mg} / \mathrm{ml})$. Whereas leaves and fruit pulp contained $0.59,0.97 \mathrm{mg} / \mathrm{ml}$ respectively. 


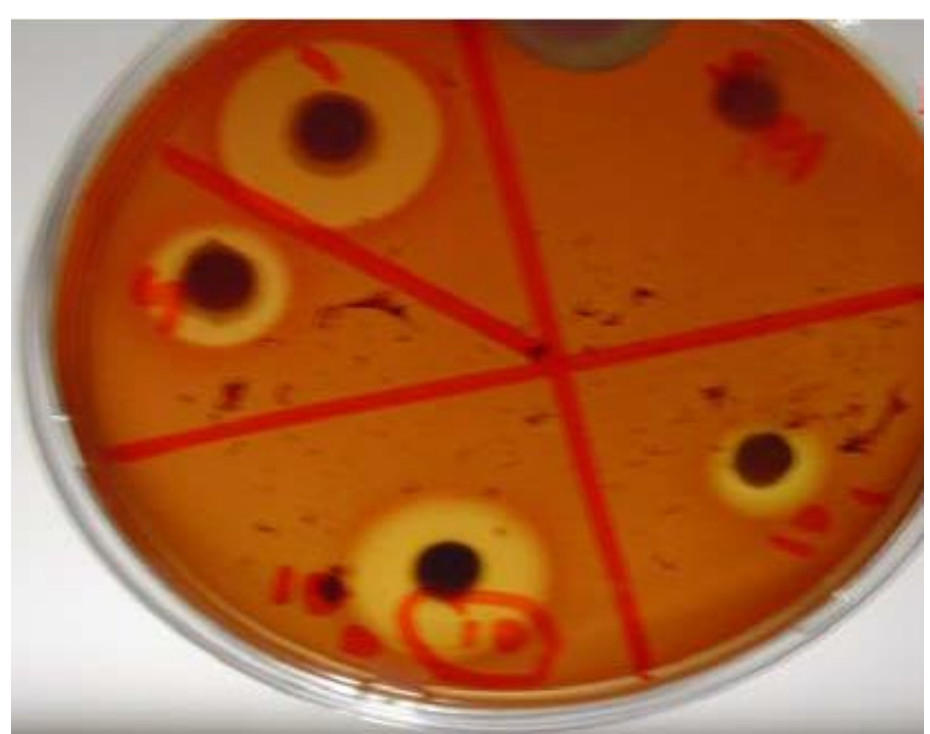

Figure 1. Haemolysis produced on blood agar plates by saponins from seeds of Gishta (Annona spp. of Ethiopia)

Table. 2. Antinutrients profile in leaves, fruit pulp and seeds of Gishta (Annona spp. of Ethiopia) determined in this study.

\begin{tabular}{|c|c|c|c|c|c|c|c|}
\hline S.No. & $\begin{array}{c}\text { Tested } \\
\text { material } \\
(\mathbf{m g})\end{array}$ & $\begin{array}{c}\text { Phytates } \\
(\mathbf{m g} / \mathbf{m l})\end{array}$ & $\begin{array}{c}\text { Saponins } \\
(\mathbf{m g} / \mathbf{m l})\end{array}$ & $\begin{array}{c}\text { Alkaloids } \\
(\mathbf{g} / \mathbf{5 g})\end{array}$ & $\begin{array}{c}\text { Cyanogenic } \\
\text { glycosides }\end{array}$ & $\begin{array}{c}\text { Trypsin } \\
\text { inhibitors }\end{array}$ & $\begin{array}{c}\text { Oxalic } \\
\text { acid. } \\
(\mathbf{m g} / \mathbf{m l})\end{array}$ \\
\hline 1. & Standard & - & 2 & 1.5 & 0 & 1931.2 & - \\
\hline 2. & Leaves & 0.06 & 0.59 & 0.14 & 0 & 358.3 & 44.6 \\
\hline 3. & Fruit pulp & 0.17 & 0.97 & 0.24 & 0 & 918.5 & 68.8 \\
\hline 4. & Seeds & 0.39 & 1.7 & 0.95 & 0 & 2872 & 24.4 \\
\hline
\end{tabular}

\section{Alkaloids}

Alkaloid precipitates measured in the test samples of Gishta are shown in table 2. Seeds had fairly high alkaloid concentration $0.95 \mathrm{mg} / \mathrm{ml}$. Low levels (less than $0.5 \mathrm{~g} / 5 \mathrm{~g}$ ) were found in leaves and fruit pulp. Their concentrations ranged from 0.14 and $0.24 / 5 \mathrm{~g}$ respectively.

\section{Cyanogenic Glycosides}

In this study, all the test samples of Gishta did not release hydrogen cyanide gas and thus the test samples were negative. Picrate paper remained yellow in all extracts, thus none of the sample contained cyanogenic glycosides as indicated in Figure 2. 


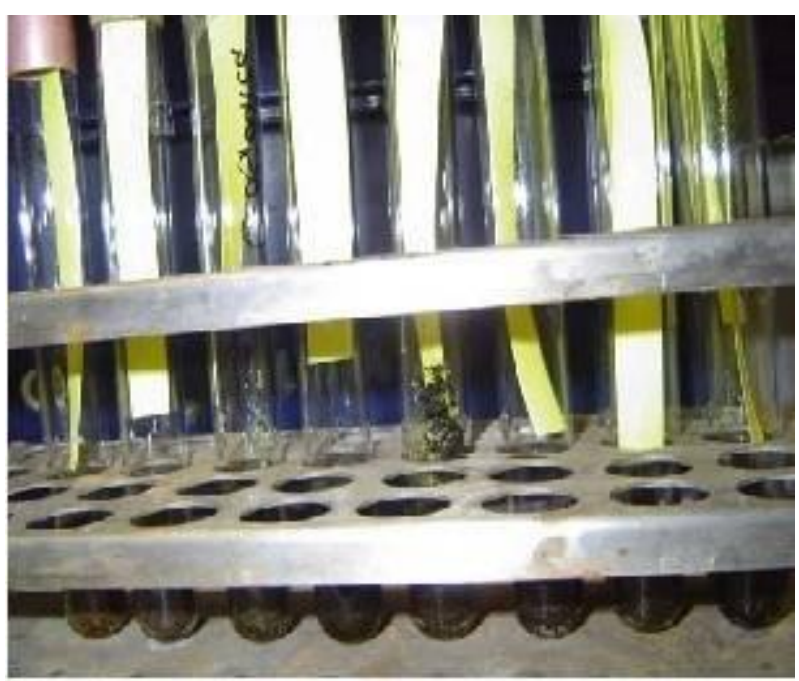

Figure 2. Detection of cyanogenic glycosides in seeds of Gishta (Annona spp. of Ethiopia) using sodium picrate paper

\section{Trypsin Inhibition}

Table 2 illustrates the results of the trypsin inhibitors. All the tested plant materials of Gishta had reduced activity of trypsin (inhibition effect) compared to the tyrosine standard. Seeds had high trypsin activity even when compared to the standard, they had activity which indicates the absence of trypsin inhibitors their activity was 2872. Whereas for leaves it was 358.3 and fruit pulp activity was 918.5.

\section{Oxalic Acid}

Oxalic acid was quantified using the HPLC. The concentrations of oxalic acid were obtained from $0.5 \mathrm{~g}$ dried plant material. All the samples were positive for this antinutrient with fruit pulp having the highest concentration followed by leaves and seeds with concentrations ranging from $68.8,44.6$ to $24.4 \mathrm{mg} / \mathrm{ml}$ respectively (Table 2 ).

\section{DISCUSSION}

There are more than 900 different phytochemicals that have been identified as components of food. It is estimated that there may be more than 100 different phytochemicals in one vegetable (Fowler, 2002). Some of these phytochemicals are antinutrients, and are said to reduce the bioavailability of essential nutrients (Aletor and Adeogun, 1995) and also cause toxicity and mutagenicity.

Phytic acid is a natural organic plant compound (Harland and Oberleas, 1986) that is a simple ringed carbohydrate with six phosphate groups attached to each carbon. It is a major phosphate storage compound in plants and can account for $80 \%$ of total phosphorous (Lopez et al., 2002). The presence of phytic acid in plants consumed may inhibit iron absorption in infants to an extent similar to that in adults. Iron deficiency in infants can lead to reduced psychomotor and mental development with long term negative consequences on school performance (Davisson et al., 1994). All the plants were found to have low concentrations of phytic acid. Seeds of Gishta contain more Phytates compared with leaves and fruit pulp. There is no information in literature regarding the relationship between the plants in this study and phytic acid, however, Sirkka (1997) reported that phytic acid markedly reduced calcium bioavailability and formed calciumphytate complexes that inhibit Fe and Zn. Phytic acid intake of 4-9 mg/100g DM is said to decrease absorption of iron by 4-5 fold in human (Hurrel et al., 1992). Depending on the amount of plant-derived foods in the diet and the grade of food processing, the daily intake of phytic acid can be as high as $4500 \mathrm{mg}$ (Reddy, 2002). In average, Reddy et al. (1982) found the daily intake of phytic acid 
to be an estimated 2000-2600 mg for vegetarian diets as well as diets of inhabitants of rural areas of developing countries, and 150-1400 mg for mixed diets.

Saponins are glycoside compounds often referred to as "natural detergents" because of their foamy texture. They are chemical structures consisting of triterpenoidal or steroidal aglycones with various carbohydrate moieties that are found in many plants. On injection, saponin, like all detergents cause lysis of the red blood cells, called haemolysis and are therefore toxic. Seeds of Gishta had the highest concentrations of saponin, it was found to have concentrations of $1.7 \mathrm{mg} / \mathrm{ml}$. Steroid and triterpenoid saponins with a single sugar chain were found to have strong haemolytic activity (Fuduka et al., 1985).

Leaves of Gishta had the lowest alkaloid concentration of $0.14 \mathrm{~g} / 5 \mathrm{~g}$ of extract while fruit pulp and seeds had fairly the high concentration of $0.24,0.95$ respectively. The fatal dose of alkaloids in humans has been reported as 50mg/kg (Van Wyk et al., 2002).

Cyanide is one of the most rapidly poisons known with a lethal dose of $0.5-3 \mathrm{mg} / \mathrm{kg}$ body weight. This is due to its ability of linking with metals $(\mathrm{Fe} 2+, \mathrm{Mn} 2+$, and $\mathrm{Cu} 2+)$ that are functional groups of many enzymes, inhibiting processes like the reduction of oxygen in cytochrome respiratory chain, electron chain transport in photosynthesis and the acting of enzymes such as catalase and oxidase (Cheeke, 1997). All the tested materials of Gishta investigated did not have any cyanogenic glycosides. The reason may be that the plant material was dried and other researchers such as Tan and Yeoh (1997) used fresh plant material.

Trypsin inhibitors, according to Venter and Van Eyssen (2001) are compounds that interfere with protein digestion, they cause pancreatic enlargement and enhance chemically induced pancreatic tumors. All the tested samples were found to have trypsin activity. However the trypsin inhibitors are heat-labile in nature and this suggests that they can be inactivated by cooking (Prathibha etal., 1995). And this also shows that if the plant material is properly cooked, the trypsin inhibitors may not interfere with digestion (Bhandari and Kawabata, 2003).

Oxalic acid is one of the antinutritional factors which are widely distributed in plant foods (Gupta, et al., 2005). All the tested samples were had oxalic acid in little amounts. A lethal dose of oxalic acid has been reported in $D$. teltoida (high oxalate containing yams) as $1 \mathrm{~kg}$ of fresh material (at once) as it contains $2 \mathrm{~g}$ oxalic acid, which is thought to be a lethal dose in humans (Libert, et al., 1987). Massey et al., (2001) advised patients who suffer from kidney stones to limit their oxalates intake to 50-60mg per day.

\section{RESEARCH HIGHLIGHTS}

$\phi$ Identified presence or absence of antinutrient compounds in leaves, fruit pulp and seeds of Graviola/Gishta (Annona spp. of Ethiopia) by using different chemical methods.

$\phi$ Discovered safety profiling of tested plant materials of Gishta (Annona spp. of Ethiopia).

$\phi$ No research report published on Graviola (Gishta) cultivar of Ethiopia in terms of antinutrient profiling.

\section{LIMITATION}

The following limitation was identified by the researchers in the present experimental study: Anti-nutrient assay methods are basically chemical reactions, multi-component analysis of metal ions with mixed reagents.

\section{RECOMMENDATIONS}

After obtaining the results discussed above the answer to the problems presented in the antinutrient profiling of leaves, fruit pulp and seeds of Gishta (Annona spp. of Ethiopia) by using different chemical methods, the researchers have arrived at the following recommendations to further improve the study: 
$\$$ The study has focused only on the antinutrient leaves, fruit pulp and seeds of Gishta (Annona spp. of Ethiopia) by using different chemical methods. In lined with this, the researchers highly recommend the phytochemical screening of pulp extracts of Graviola (Gishta) cultivar of Ethiopia for the identification of its specific active bio ingredient.

$\phi$ Future research can be encouraged to determine the effect of different plant parts of Graviola (Gishta) of Ethiopia, in the metabolism and other physiological function.

\section{CONCLUSION}

The leaves, fruit pulp and seeds of Gishta (Annona spp. of Ethiopia) evaluated in this study are well endowed with all of the essential nutrients required for human nutrition. Should also be cautioned as they have indicated high antinutrient content especially trypsin inhibitors and alkoloids. All the tested samples contained antinutrients in varying concentrations. Consumption of this plant with low concentrations of antinutrients may appear safe at face value, but it should be noted that consumption of these plant materials over a long period as may contribute to adverse accumulative effects in the consumer. Thus further investigation with respect to the accumulative effect and toxic doses need to be established.

\section{ACKNOWLEDGEMENT}

The authors which to appreciate the effort of Prof Behailu Etana Disasa of Natural Resource Management, College of Agriculture and Veterinary Medicine, Jimma University, Jimma, Ethiopia-307 and University of Oslo, Faculty of Mathematics and Natural Science, Centre for Ecological and Evolutionary Synthesis (CEES), University of Oslo, Oslo, Norway for identification, authentication and supplying experimental plant material; Lydia Swapna Nandam of Department of Microbiology \& Genetics, Institute of Fundamental Sciences, Massey University, Palmerston North-4474, New Zealand; Management of Aksum University, Axum, Ethiopia-1010, North East Africa for providing the basic facilities required for completing the work and especially the corresponding author highly grateful to Prof K R S Sambasiva Rao, Prof D M Prasad, Dr K Ammani for their constant support and encouragement extended.

\section{REFERENCES}

Aletor, V.A. Adeogun, O.A. 1995. nutrient and antinutrient components of some tropical leafy vegetables. Food chemistry 53: 375-379.

"Avis de l' Agence française de sécurité sanitaire des aliments relatif aux risques liés à la consommation de corossol et de ses préparations" (pdf). Agence française de sécurité sanitaire des aliments. 28 April 2010. Retrieved August 2013.

Bhandari, M.R. Kawabata, J. 2003. Assessment of antinutritional factors and bioavailability of calcium and zinc in wild yam (Dioscorea spp) tubers of Nepal. Journal of food chemistry, 85: 281-287.

"Can graviola cure cancer?". Cancer Research UK. Accessed: 2013-11-12.

Cheeke, P.R .1997; 1990. Ph.D., Oklahoma State University, Stillwater, Oklahoma.

Davisson, L. Galan, P. Kastenmayer, P. Cherouvier, F. Juillerar, M.A. Hercberg, S. Hurrel, R.F. 1994. Iron bioavailability studied in infants: the influence of phytic acid in infant based formulas based on soy isolate. Pediatric Research BC: 816-822. 
Edeoga HO, Gomina A (2000). Nutritional values of some noncomventional leafy vegetables of Nigeria. J. Econ. Taxon. Bot. 24:7-13.

Edeoga H.O., Okwu D. E and Mbaebie B.O (2005). Phytochemical constituents of some Nigerian medicinal plants. African Journal of Biotechnology Vol. 4 (7), pp. 685-688.

Fowler, L.K. 2002. Phytochemicals help plants, humans. Crawford connections Pp3.

Fuduka, K. Utsumi, H. Shoji, J. Hamada, A. 1985. Saponins can cause the agglutination of phospholipid vesicles. Biochimica et biophysica Acta 820: 199-206.

Grant, F.W. 1998. Higher Plant Assays for the Detection of Genotoxicity in Air Polluted Environments Ecosystem Health 4 (4): 210-229.

"Graviola". Memorial Sloan-Kettering Cancer Center. Retrieved November 2013.

"Graviola (Soursop)". Blackherbals. Retrieved 30 January 2012.

Guil, J. L. Torija, M. E. Giménez, J. J. Rodríguez-Garcia, I. Giménez, A. 1996. Oxalic acid and calcium determination in wild edible plants. Journal ofAgricultural and Food Chemistry 44 (7), 1821-1823.

Gupta, S. Lakshmi, J.A. Manjunath, M.N. Prakash, J. 2005. Analysis of nutrient and antinutrient content of underutilized green leafy vegetables. LWT Food Science and Technology, 38: 339-345.

Harborne JB, (1984). Phytochemical methods, 2nd edition, Chapman and Hall publications, London, NewYork, pp. 288.

Harikrishna Ramaprasad Saripalli (2012). "Antimicrobial studies on conventional \& cultured Plant tissue extracts” . I ed, ISBN 978-3-8484-9799-7. LAP Lambert Academic Publishing AG \& Co. KG, HeinrichBöcking-Straße 6-8, 66121 Saarbrücken, Germany.

Harikrishna Ramaprasad Saripalli and Prasanna Kumar Dixit (2016). Studies on morphological features and biological activities of the genus Annona of Ethiopia, N. E. Africa with a special emphasis on Graviola: A Review. International Journal of Science and Research (IJSR) 05 (02): 821-827.

Harland, B.F. Oberleas, D. 1986. Phytates in food. In changes in methods. Journal Association of Analytical Chemistry 69(2): 356-357.

Higashimoto, M. Purintrapiban, J. Kataoka, K. Kinouchi, T. Vinitketkumneun, U. Akimoto, S. Matsumo, H. Ohnishi, Y. 1993. Mutagenicity and antimutagenicity of extracts of three species and a medicinal plant in Thailand. Mutation Research 303: 135- 142.

Hurrel, R.F. Juillert, M.A. Reddy, M.B. Lynch, S.R. Dassenko, S.A. Cook, J.D. 1992. Soy protein, phytate and iron absorption in humans. American Journal of Clinical Nutrition. Iranian Medicine 2(3) http://www.snms.ac.ir/AIM/9923/contents9923.html

Jayaraman, J., 1981. Laboratory Manual in Biochemistry. Wiley Eastern Ltd., New Delhi, India, pp: 53.

Kassie, F. Parzefall, W. Musk, S. Johnson, I. Lamprecht, G. Sontag, G. Knsmuller, S.1998. Genotoxic effects of crude juices from Brassica vegetables and juices and extracts from phytochemicals preparations 
and spices of cruciferous plants origin in bacterial and mammalian cells. Chemical and biological interactions 27:1-16.

Lea, P.J. Leagood, R.C. 1999. Plant biochemistry and molecular biology. Wiley, London. Pp 34-36.

Libert, B. Franceschi, V.R. 1987. Oxalates in crop plants. Journal of agriculture and food chemistry 28:1313-1315.

Lopez, H.W. Leenhardt, F. Coudray, C. R'eme'sey, C. 2002. Mineral and phytic acid interaction: is it a real problem for human nutrition? International journal Food Science Technology 37: 727-739.

Makkar HPS. Assessing quality and safety of animal feeds. Vol. 160. FAO Animal Production and Health; Rome, Italy: 2004. Recent advances in the in vitro gas method for evaluation of nutritional quality of feed resources; pp. 55-88.

Massey, L.K. Palmer, R.G. Horner, H.T. 2001. Oxalate content of soybean seeds (glycine max: Leguminosae), soya foods and other edible legumes. Journal of agriculture and food chemistry 49: 42624266.

Miller, R. Woodraw, I. 2004. Kakadu plum chemical analysis: cyanogens, alkaloids, and oxalate. Plant Physiology research group, School of Botany, University of Melbourne. Pp 146- 148.

Omotoso OT. 2006.Nutritional quality, functional properties and anti-nutrient composition of the larva of Cirinaforda (Westwood) (Lepidoptera: Saturniidae). J Zhejiang University Sci B., 7(1): 51-55.

Prathibha, S. Bala, N. Leelama, S. 1995. Enzyme inhibitors in tuber crops and their thermal stability. Plant foods for human nutrition 48: 247-257.

Reddy, N.R. 2002. Occurrence, distribution, content and dietary intake of phytate. In: Reddy, N.R., Sathe, S.K. (Eds.). Food phytates. CRC press, Boca Raton, Florida Pp 25- 51.

Reddy, N.R. Sathe, S.K. Salunkhe, D.K. 1982. Phytates in legumes and cereals. Advanced food research 28:1-92.

Siddhuraju, P. Mohan, P.S. Becker, K. 2002. Studies on the antioxidant activity of Indian Laburnum (Cassia fistula L.): a preliminary assessment of crude extracts from stem bark, leaves, flowers and fruit pulp. Food Chemistry 79: 61-67.

Sirkka, P. 1997. Myoinositol phosphate: analysis, content in foods and effects in nutrition. LebensmittelWissencschaft und Technologie 30(7): 633-647.

Tan, S.L. Yeoh, H.H. 1997. A comparison of two methods based on sodium picrate for determining cyanogens content in cassava roots. Journal of tropical Agriculture and food Science 25(2): 139-143.

Van Wyk, B.E. Van Heerden, F. Van Oudtshoorn, B. 2002. Poisonous plants of South Africa. Briza publications, Pretoria, South Africa. Pp.65-80.

Venter C.S. Van Eyssen E. 2001. More legumes for better overall health. South African Journal of Clinical Nutrition 14(3): 532-538. 
Wheeler E. L. and Ferrel R.E (1971). A method for phytic acid determination in wheat and wheat fractions. Cereal Chem, 48: 312-320.

Yen, M.R. Tseng, Y.H. Saier, M.H.Jr. 2001. Maize Yellow Stripe1, an ironphytosiderophore uptake transporter, is a member of the oligopeptide transporter (OPT) family. Microbiology 147(11): 2881-2883.

\section{Author Profile}

Dr Harikrishna Ramaprasad Saripalli received B.Sc (Zoology, Botany and
Chemistry), M.Sc. (Microbiology), M.Phil (Botany) from Acharya Nagarjuna
University, PhD (Biotechnology) from R P S C (MU), Patna and PDR
(Biotechnology) from Dept. of Biotech, AkU in 1995, 1997, 2004, 2007 and
2015, respectively. During March 97- Jul 97, he stayed in as microbiologist in
quality control section at Sangam Diary- Packaging industry; Aug '97 to Mar '07
worked as teacher and researcher at Department of Microbiology and
Biotechnology, St. Ann's College in capacity of Vice Principal, Dean-academics
and administration, Head and Staff Secretary; Apr '08-Jun '10 rendered services
as a Professor and Head, Department of Pharmaceutical Biotechnology, SIMS
College of Pharmacy; Jun '10-Oct'11 worked as an Assistant Professor, Prof in
charge for P.G. Exams, Term paper, Mini Project and Ph.D research Program at
Department of Biotechnology, K L E F University. He is now with Department
of Biotechnology, Aksum University, Axum as an Associate Professor and Chair
Person-BtCDDC (Biotechnology Curriculum Design and Development
Committee).

